\title{
THE POLITICS OF EROTICISM: POLITICAL WRITING AND ARUNDHATI ROY'S THE GOD OF SMALL THINGS
}

\author{
DharmaThapa, Lecturer of English \\ Tribhuvan University, Birendra Multiple Campus, Bharatpur \\ dharmabahadurthapa@hotmail.com
}

\begin{abstract}
This article analyses the erotic relationships between sexes depicted in Arundhati Roy's novel The God of Small Things in the binary opposition: those based on bourgeois patriarchal dominance and that based on equality and mutual respect. It focuses on the relationship between Ammu and Velutha as love, in diametrical contrast with the former pattern, based on independent choices and guided and inspired by radical politics.
\end{abstract}

KEYWORDS: Patriarchy, traditional, alternative, equality

\section{INTRODUCTION}

Arundhati Roy's only fictional work The God of Small Things depicts many types of social, political, and ideological conflicts that operate in the post-independent India, and presents radical alternative vision to deal with them. The class/caste problem, the suppressive Indian state machinery and the Maoist movement, the role of the media in corporate globalisation and consumer culture and ecological damages, parliamentarian Marxism and its complicity with the Indian establishment, and relationship between sexes founded on male dominance and so on. She usually raises these issues in contrastive pairs, in opposing sets: one the oppressive and dominant, the other suppressed but radical and emergent. She embodies her radical vision in her preference and privileging the latter. In the novel, for example, she presents the age long discriminatory caste system, which divides people into the touchable and untouchable categories, operating even among the educated strata of the present Indian society. As a cruel and unjust practice, she highlights and privileges the AmmuVelutha love that subverts and breaks it. On the other hand, she presents the relationship between Pappachi and Mammachi (the husband and wife), which conforms to the socially accepted norms and patterns, as a compulsive and oppressive bond (for the latter) without love.

In this article, I have attempted to show how Ammu-Velutha affair radically differs from the other love relations that the novel depicts. I have also shown how it prefigures Roy's alternative vision of what man-woman relationship should be like. In other words, I assume that, as in other issues, her radical view on love and marriage has become manifest in Ammu-Velutha relationship, which, unlike other love patterns in the novel, is not based on subordination of women to men but based on independence, mutual respect and equality. The Ammu-Velutha erotic relationship, as the central part of the plot, is Roy's alternative vision of love. While dealing with this axis, I will be drawing on the theories of Karl Marx and Fredrick Engels, Simon de Beauvoir and others to show how it embodies their ideas to interpret the text. 


\section{Crossing the Border: International Journal of Interdisciplinary Studies}

\section{TRADITIONAL PATTERNS OF MALE DOMINANCE OVER WOMEN}

The relationship that operates under feudal and capitalist social system signifies absolute dominance of males over females. Despite the fact that capitalist modernity talks of 'equality and freedom between sexes', it merely treats women as commodity. So both feudal and capitalist pattern of relationship between sexes is relationship without sexes. Simone de Beauvoir holds that there cannot be true love based on equality between sexes in the existing socio-economic and cultural condition. According to her,

For loyalty and friendship to exist between man and wife, the essentialcondition is that they both be free in relation to each other and be equal in concrete matters. Since man alone possesses economic independence and since he holds - by law and custom- the advantages attached to masculinity, it is natural enough for him to appear a tyrant. . . (488)

Beauvoir unequivocally stresses that under feudal or capitalist system, husband wife relationship is tyrannical for women because the husband controls the property, and even law and custom favour his privileges. She also remarks that women are destined to live the repetitive life which restricts their freedom (540). She holds the opinion that feminity is not a homogeneous and uniform category. Women are also divided into classes, so their ideas, attitudes and beliefs are, to a large extent, determined by the class/es to which they belong. Highlighting this side of the matter, she remarks, In the upper classes women are eager accomplices of their masters because they stand to profit from the benefits provided. We have seen that the women of the upper middle classes and the aristocracy have always defended their class interests even more obstinately than have their husbands, not hesitating radically to sacrifice their independence as human beings. They repress all thought, all critical judgement, all spontaneous impulses; they parrot accepted opinions, they confuse with the ideal whatever the masculine code imposes on them; all genuineness is dead in their hearts and even in their faces. (638)

From what Beauvoir has asserted, we can conclude that upper class women are incapable of becoming feminists because they easily adopt and internalise the upper class male values. The reason behind this is, as she argues, that they benefit from the class position of their husbands. They become loyal more to the class than to the sex. Hence, they become the most misguided and conservative lot. However, their regressive standing does not prevent them from being the oppressed. In order to see Beauvoir's idea on malefemale relationship in Roy's novel, we can analyse the roles and positions of Pappachi and Mammachi relation in this light.

The original name being Shri Benaan Ipe, he is mentioned as Pappachi throughout the novel. He is husband to Mammachi and father to Chacko and Ammu. He comes from a Hindu feudal family. He was an Imperial Entomologist in the final years of the Colonial period. After Independence he became "Joint Director, Entomology" (The God 49). His daughter, Ammu, takes him to be "shit-wiper" of the British Imperial masters and Chacko, the son terms him as "Anglophile" (The God 51, $52)$. He is very fond of and loyal to the British power and manners which he attempts to imitate to the extent it is practicable for him (The God 49). Putting his feudal native background and his comprador role during the imperial period together, we can situate him on the upper class. His servile imitation of the British mannerism reminds 


\section{THE POLITICS OF RADICAL}

the reader of Bhabha's famous mimic man who is 'almost the same not quite' like the colonial masters (89).

The relationship between him and his wife, Mammachi, is that of the oppressor and the oppressed. She is treated as a baby producing machine by him. He takes it for granted that it is right and duty for him to torture and bully the wife. He is seventeen years older than her and his being much older irritates him greatly (The God 47). He turns jealous of her youth and the attention she gets. His jealousy turns into physical violence (The God 48). But the point of importance is that Mammachi, instead of resisting or feeling dissatisfied with this kind of treatment, accepts it, or to say more accurately, feels proud of her husband and his wealth (The God 168). This is possible for her to do so because she belongs to the upper class and shares in exploitation. This is possible because her class position has overtaken her gender. Beauvoir's comment on the upper class women totally applies to her. Later in the narrative, Mammachi collaborates with the conspirators against Velutha and her own daughter Ammu and becomes one of the factors for their ruin.

Elaborating the positions of women characters in Roy's novel in totality, Alex Tickell remarks that "Roy's narrative is unrelenting in its need to bear witness to the routine cruelties of patriarchy (male authority), and women characters are consistently bullied, harassed and made to defer to the needs of male relatives and family members" (35). This means that, in the matter of exploitation of women, the Ipe family represents the Indian society itself. The male-female relastionship operating in the family shows the dominant pattern of love that operates in the society as a whole.

Ammu's married life illustrates the maltreatment of wives by their husbands. It shows the extent to which a woman can be bullied in a male dominated society. Ammu, though a child of Pappachi and Mammachi like Chacko, suffers only because she is a female. She has to jump into a hasty marriage to a "full-blown alcoholic" because she wanted to "escape from her parents' home at Ayemenem" (The God 39). As he is about to lose his job at the tea estate due to his drunkenness and carelessness, he offers her to sleep with Mr. Hollick, the English estate manager, so that he might resume his job. She resists it and gets divorce from him and, with her twin children, takes shelter in her parents' home. She and Chacko are the children of the same parents, Mammachi and Pappachi. But due to the discriminatory tradition, they are treated differently. As a male child, he is privileged and inherits the property and the title of the family whereas as a married daughter, Ammu is dispossessed. The point to be debated here is that both have suffered failed marriages. Both have extra marital affairs. Ammu's is a more progressive and justifiable affair because it is not based on domination but on independence and free choice of the concerned parties. However, Ammu is marginalised and severely punished, but in case of Chacko, it makes no difference. Rather, he is encouraged. Although she works very hard in the pickle factory owned by the family, her place in the family and contribution are not recognised and her condition there is like those of the Palestine refugee. She becomes a woman without a locus in her parents' home (The God 57). Here, Chacko's over possessive temperament leaves her in the more marginal position.

Despite avowed alignment with Marxism and the Marxist party, Chacko is a bully to working women in multiple ways. He exploits their labour by underpaying them and exploits them sexually. If Pappachi's domination of his wife represents feudal attitude to women, his domination stands for bourgeois attitude because as a 


\section{Crossing the Border: International Journal of Interdisciplinary Studies}

factory owner, he underpays them and treats them as commodities. His relationship with the working women is presented thus,

Chacko was a self-proclaimed Marxist. He would call pretty women who worked in the factory to his room, and on the pretext of lecturing them on labour rights and trade union law, flirt with them outrageously. He would call them Comrade, and insist that they call him Comrade back (which made them giggle). Much to their embarrassment and Mammachi's dismay, he forced them to sit at table with him and drink tea. (The God 65)

So the relationships that operate in the novel, including in the Ipe family and in the pickle factory run by the family, is founded on the domination and exploitation of women by men. In all these episodes, the females are guided by the dominant ideology which prevents them from understanding their unbearable subordinate position. They either accept the situation as destiny that cannot be altered, or in some cases feel self-satisfied. Even the local leader of the Marxist party, Comrade Pillai, proudly professes that Kalyani, his wife, is the "Boss" of the house (The God 278). He does not mean to say that she really has deciding power in internal matters. It simply implies that she does not have any role to play outside the kitchen. In other words, this is to admit that Pillai has imprisoned his wife in the house, disallowing her any excess outside the boundary of the four walls. But with Ammu, the case is radically different. She has the consciousness and capacity to understand and subvert the nature of the relationship and the foundation on which it operates.

\section{AMMU-VELUTHA EROTIC RELATION: A RADICAL ALTERNATIVE}

In this section of the article, I will now discuss the erotic relationship between Ammu and Velutha as a radical alternative to the dominant pattern of male female relationship based on the submission of the latter to the former. In other words, I want to show how it prefigures the emancipatory vision founded on mutual respect, equality and devoid of subordination.

In his essay "Principle of Communism," Frederick Engels, the co-propounder of the theory of scientific communism along with Karl Marx, has thrown light on how the communistic order will bring about a change in the existing pattern of the family,

It will make the relations between sexes a purely private affair which concerns only the persons involved, and calls for no interference by society. It is able to do this because it abolishes private property and educates children communally, destroying thereby the two foundation stones of hitherto existing marriage- the dependence of the wife upon her husband and of children upon the parents conditioned by private property. (Selected Works 94)

Here, Engels outlines the abolition of private property as the precondition for the independence and equality of sexes because its existence always engenders and strengthens male dominance. We have practically realised that women of the working class enjoy more freedom than their upper class counterparts. He also stresses that love between sexes should be free and purely personal affair in which society should not interfere. But, as he implies, as long as the bourgeois society exists, the dependence of the wife upon the husband will retain. We have seen this working in the novel in the relationships of the aforementioned characters. Now we have to see how far Ammu-Velutha love fulfils this.

Beauvoir also has expressed similar notion regarding the precondition for 
THE POLITICS OF RADICAL

women's emancipation. She maintains,

For loyalty and friendship to exist between man and wife, the essential condition is that they both be free in relation to each other and be equal in concrete matters. Since man alone possesses economic independence and since he holds - by law and custom- the advantages attached to masculinity, it is natural enough for him often ... and this drives woman to revolt and dissimulation. (488)

Beauvoir concedes that certain 'concrete matters' must be present in the society for the freedom and equality between the sexes. Although she does not explicitly point out, her concrete matters are nothing but equal economic condition for women because in the present context man alone holds it. With this position, he dominates the woman. She also holds law and custom responsible for women's subordinate position. So putting Engels and Beauvoir together, we can come to the conclusion that women, if they desire equality and freedom, have to fight not only against male domination but they have to go also against the bourgeois economic and cultural structure itself which gives rise to inequality. This means that they have to be radical. Being a mere reformist does not work. Let's see how Roy's novel fulfils this necessity.

Ammu-Velutha love relationship operates on a qualitatively different ideological and political plain. Velutha is a Paravan, the untouchable caste, and an accomplished carpenter. He is 'the god of small things' (The God 217). He is a proletariat in the true sense of the word. "There were no keys or cupboards" in "his hut" because he has no fear of losing anything (The God 208). He is associated with the Naxalite, the Indian Maoist party which "aimed at smashing the state power through protracted people's war and establishing the dictatorship of the working class" (qtd in Singh 41). His involvement in radical movement is heightened by frequently associating him with red colour. He is pictured as a "carpenter with gaudy nails" (190), "blood-red nails" $(191,307)$ and "red varnish on his nails" (288). Just before death, he bleeds too much and the bleeding is "the blood on his breath bright red" (310). These images signify his radical politics which makes him resist the dominant social, cultural, political and ideological forces.

Ammu, though comes from a rich Brahmin family, as a divorcee with twin children to bring up, has been reduced to a woman without a place, identity and property (The God 57). Her marginal position conversely enables her to see that caste is a way devised by the power to exploit and dominate the working masses and sharpens her consciousness about the true nature of the social institutions and their oppressiveness. This takes her closer to the untouchable Velutha; she loves him and has sex with him. This makes her a woman of strong taboo breaking, society challenging will power which enables her to make impossible possible. She is pictured as

What was it that gave Ammu this Unsafe Edge? This air of unpredictability? It was what she had battling inside her. An unmixable mix. The infinite tenderness of motherhood and the reckless rage of a suicide bomber. It was this that grew inside her, and eventually led her to love by the night the man her children loved by day. (The God 44)

Here, the narrator highlights Ammu's temperament which is imbued with radical passion which enabled her to love Velutha by violating social, traditional and taboos. Their transgressive love has multiple dimensions. First of all, it has broken class and caste restrictions erected by the unjust tradition. Secondly, it has undermined the in- 


\section{Crossing the Border: International Journal of Interdisciplinary Studies}

terfering role of the family in the relations between sexes and shown that love is, and should be, a totally private matter as envisaged by Engels and Beauvoir. Thirdly, by highlighting and privileging subversive/transgerssive love as ideal, Roy is indicating that independence for women should be sought outside the institution of marriage. All other relations between sexes in the novel, without exception, are oppressive for women. So Roy has shown that women's liberation is not possible as long as marriage exists.

The detailed presentation of the erotic scene in the novel also contains the radical element. Besides being sensuous/sensual, it is political. The novel places Ammu as the initiator in the erotic affair, unlike the male's initiation in such matters. The erotic experience is presented through her gaze and perspective:

... As she watched him she understood the quality of his beauty. How his labour has shaped him. How the wood he fashioned has fashioned him. Each plank he planed, each nail he drove, each thing he made, has moulded him. Had left its stamp on him. Had given him his strength, his supple grace.

... She could see his smile in the dark. His white, sudden smile that he had carried with him from boyhood into manhood. His only luggage. (The God 334)

Besides presenting the beauty of male body from woman's point of view, Roy has conflated the quality and concept of beauty with labour. She has shown that one who does physical labour is beautiful. In other words, labour creates beauty. This goes in contradistinction with the bourgeois concept of beauty which is founded on the assumption that one who works is uncivilised and unrefined, hence ugly. Hatred of the working class is the foundation of the bourgeois concept of beauty. Roy's depiction of love is certainly a radical/Marxist concept.

However, the point of the strength of Roy's novel is also its point of weakness. The Ammu Velutha erotic episode has, as the heart of the plot, drawn as much criticism as it has drawn admiration. Aijaj Ahamad, for example, argues that the portrayal of the erotic as the real zone of rebellion and truth in the sense of resistance can be individual and fragile (108). He is not ready to accept that sexual relationship of whatever kind can be a form of resistance because it is very personal. As a Marxist critic, he believes in the collective actions of the working class as only means of resistance Ahamad also claims that Roy has highlighted caste issue at the cost of the class. For these and other political/ideological reasons, namely the controversies related with the mainstream Left in India, he concludes that the novel contains an anti-communist ideology.

But Brinda Bose has defended the Ammu-Velutha eroticism as a zone of resistance against the criticism forwarded by Ahamad. She believes that their relationship transcends personal and cultural significance. It is more than physical lust and attraction induced by naturalistic urges. It is physical and spiritual union founded on common cause. It is a combination of two oppressed souls to generate strength against the forces against which they are fighting and without the fight they cannot prove their existence. In her words,

Apparently Ammu is not dismissive of Velutha's red politics, sees in its inherent anger a possibility of relating to Velutha's mind, not just his body. Her own politics are embedded in her 'rage' against the various circumstances of her life, and it is through this sense of shared raging that she finds it possible to desire the Untouchable Velutha. It is not only sexual gratification that she seeks; 


\section{THE POLITICS OF RADICAL}

she seeks also to touch the Untouchable. (Emphasis added qtd. in Tickell 125) The sense of shared raging requires a little elucidation. Their shared raging is, no doubt, against the dominant social, political, cultural, economic and ideological forces which exploit, suppress and marginalise the working class, including the 'untouchable' and women.

As a woman, like Velutha as an outcaste, Ammu is also reduced to the proletarian status in which she has nothing to lose, except her owes. Her awakened state of mind also played a role to make impossible be possible. Bose further highlights the radical aspect of the relationship:

Velutha, nurturing anti-caste/class aspirations in love/desire, is seen as a more fully committed political being because of his participation in the communist uprising in the state. . In any case, there are indications in the text that parallels can be drawn between the politics of Ammu and the rather more obvious Leftist leanings suspected of Velutha, and that hers are probably as viable, though more personal. (qtd in Tickell 125)

In fact, Ammu expects Velutha to have involved in the protest of the workers which frightens her bullying aunt Baby Kochamma. When she is sure that Velutha was really seen in the protest by her children, she silences them so that the matter might not be disclosed. She rather appreciates Velutha for his involvement (The God 17576). This shows that their relation is inspired by the common social and ideological ground more than anything else.

Critics like Narendra Tiwary and N. D. R. Chandra also have found radical politics which poses threat to the characters representing dominant order in Roy's novel (92). Roy frankly admits that she projects the same ideology whether it is her fiction or nonfiction or even in her activism. Regarding the role of women in political/social movements, she remarks that "a political struggle that does not have women at the heart of it, above it, below it, and within it, is no struggle at all" (An Ordinary 351-52). In fact, if Velutha represents the radical force of the Naxalite movement, Ammu represents the woman counterpart who is "at the heart" of it. Their symbiotic union fulfils requirement of an all-round political resistance.

\section{CONCLUSION}

As a writer involved in political activism and polemical writing, Roy does not limit herself to critiquing what is wrong in the present, but also offers her vision of what could be better solution for the future. In other words, she is guided by the idea that things can be changed and a better alternative world is possible (The Shape 215-16). Her novel also critiques the dominant pattern of male-female relationship which operates on the subordination of women to men. She has done this by presenting various such relations which are oppressive to women. Diametrically opposed to this, the novel depicts Ammu-Velutha erotic relationship on a different light as an alternative vision. Their relation takes place and thrives on free choice and independence of both of the agencies. It is based on mutual likes and respect and understanding. They are not inspired by mere physical lust or need; but the identical attitude to and common experience of life have brought them together. Their love is a form of resistance to the social pattern which engenders and encourages class/caste/gender divide. By romanticising and foregrounding love outside marriage, and outside the accepted traditional caste/class and age requirements (Ammu is older), Roy indicates 


\section{Crossing the Border: International Journal of Interdisciplinary Studies}

that marriage itself, as an institution, is oppressive to women. Hence, they cannot be free as long as it exists. Ideal relationship between sexes should be sought outside marriage. This is the radical vision of love presented in Roy's novel.

\section{WORKS CITED}

Aijaj, Ahamad. "Reading Arundhati Roy Politically." Frontline 8 Aug 1997: 103-108. Print.

Beauvoir, de Simone. The Second Sex. London: Vintage Classics, 1997. Print. Bhabha, Homi K. The Location of Culture. London: Routledge, 1997. Print.

Marx, Karl and Fredrick Engels. Selected Works Vol. 1. Moscow: Progress publishers, 1977. Print.

Roy, Arundhati. The God of Small Things. New Delhi: Penguin Books, 2002. Print. ---. An Ordinary Person's Guide to Empire. New Delhi: Penguin Books, 2002. Print. ---. The Shape of the Beast. New Delhi: Penguin Books, 2009. Print.

Singh, Prakash. The Naxalite Movement in India. New Delhi: Rupa, 2010. Print. Tickell, Alex. Arundhati Roy's The God of Small Things. London: Routledge, 2007. Print. Tiwary, Narendra and N. D. R. Chandra. "New Historicism and Arundhati Roy's Works." Journal of Literature, Culture and Media Studies 1 (2009): 79-96. Print. 